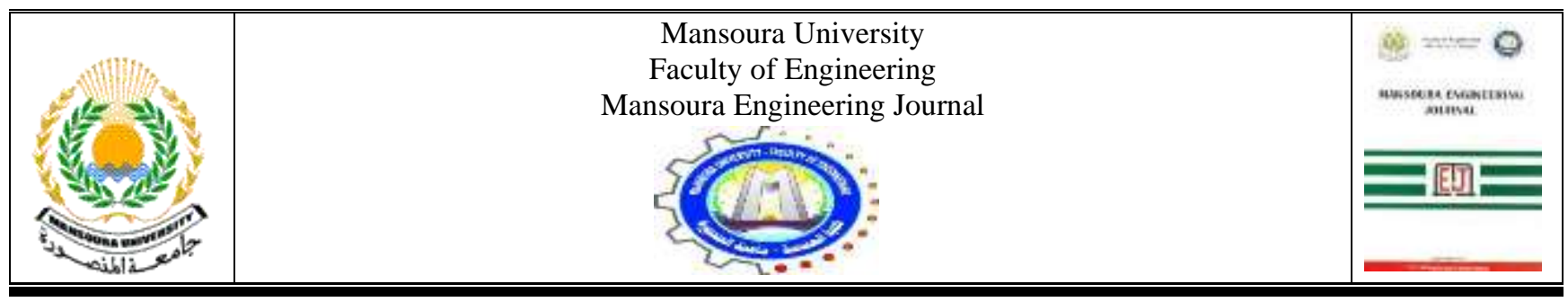

\title{
Use of Steel Slag in Eco-Frienfly Rigid Pavement
}

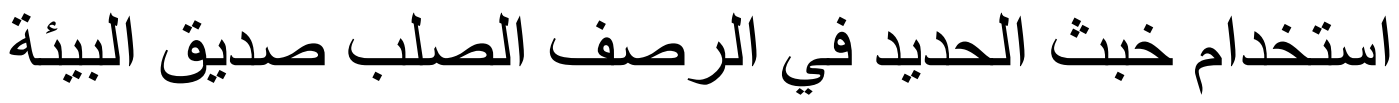

Ahmed Mohamed Tahwia, Ahmed Hasanen Abd El Raheem and Ahmed Khaled Elalfy

KEYWORDS:
Recycling, $\quad$ Rigid
pavement, Steel slag,
Compressive strength,
Tensile strength.

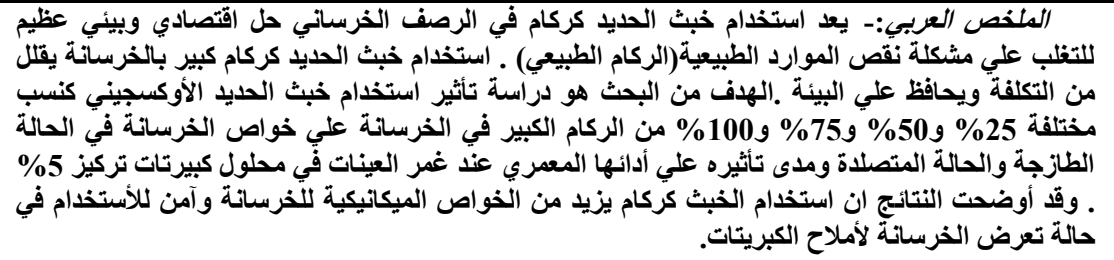

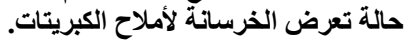

\begin{abstract}
The use of steel slag aggregate in rigid pavement presents a great economical and environmental solution to overcome the decreasing in natural aggregate. The aim of this research is to investigate the potential recycling of Basic Oxygen Furnace Slag (steel slag) in road construction for sustainability an environmental benefit. The steel slag is used as a coarse aggregate replacement in rigid pavement mixes, partly or totally. Recycling ratios of $25 \%, 50 \%, 75 \%$ and100\% are used. The results showed that using steel slag aggregate increases the mechanical properties of concrete, safe to use as aggregate at sulfate attacking when samples were submerged in $5 \%$ sulfate solution concentration.
\end{abstract}

\section{INTRODUCTION}

A LARGE amount of roads project is constructed in present time in Egypt, for that this research is seeking to use rigid pavement substitute to flexible pavement because it's durability, stiffness, and ability

Received: Received: (5 September, 2019) - Accepted: (13 January, 2020) Ahmed Mohamed Tahwia, Prof., structural Engineering Dept. Faculty of Engineering, Mansoura University, Mansoura, Egypt. (e-mail: Atahwia@mans.edu)

Ahmed Hasanen Abd El Raheem: Prof., structural Engineering Dept. Faculty of Engineering, Mansoura University, Mansoura., Egypt (e-mail: ahmed_abd_el_raheem@hotmail.com)

Ahmed Khaled Elalfy: MSC. Student, structural Engineering Dept. Faculty of Engineering, Mansoura University, Mansoura, Egypt. (e-mail: engelalfy777@yahoo.com) to bear high traffic loads and began to use it in Cairo-Suez road in 2015.But its resistant is high cost, so that the researcher's started to get solutions to decrease its cost such as using recycled materials as substitution in concrete composition.

Recycling and environmental management are all precepts that are more common in many appearances of life, including concrete paving. The greatest potential for recycling slag aggregate at a high value is to utilize it as aggregate in new concrete slabs whereat the dolomite or gravel and sand, constitute the major component of pavement concrete, representing about $70 \%$ of the volume of concrete so utilizing Slag aggregate (SA) as a replacement for natural aggregates is a way to potentially address these economical and environmental concerns [1].

Efforts to preserve non-renewable resources and reduce the related negative environmental influences continue to be a research motivation for researchers and scientists. These efforts represent investigating the potential recycling of industrial by-products materials in road paving one example of these by-products is ferrous slag from steel and iron industries [2].

The term ferrous slag prescribes slag that is produced during steel and iron production and casting. Depending on the steel and iron production process, many slag types can be generated, generally known as blast furnace slag and steel slag. Blast furnace slag is made during the melting and 
reduction of iron ore in a blast furnace, while steel slag is produced during the converting of hot metal to steel or during the melting of scrap in different types of furnaces [3].

Using steel slag aggregate in concrete mixtures has verified to be useful in solving some of the challenges encountered in the concrete industry. Steel slag was used in normal concrete to enhance its mechanical, chemical, and physical properties [4].

Basic Oxygen Furnace Slag (BOFS) is a hot liquid blast furnace metal and fluxes, which consists of $(\mathrm{CaO}-\mathrm{MgO})$ and $(\mathrm{CaO})$. They are initially charged into furnace react and remove the faults in the charge. Those faults mainly are generated by carbon as gaseous, and silicon, magnesium, phosphorus and some iron oxide, which react with (lime and dolomite) to form BOFS.

Kothai et al. made different mixes of different replacement ratio of steel slag from $10 \%, 20 \%$ up to $100 \%$ and slump test in this mixes decrease from $100 \mathrm{~mm}$ to $85 \mathrm{~mm}$ with increasing in replacement [5].

Lizadeh et al. prepared four mixtures normal, slag aggregate concrete, and high strength concrete with normal and slag aggregate. The results showed that the normal concrete with slag aggregate higher than the normal concrete with normal aggregate and near to HSC strength because of mechanical and physical properties of Steel aggregate [6].

Ameri et al. showed that The flexural strength of Slag aggregate concrete is higher than normal concrete aggregate because of high roughly surface of slag that increase the bond with concrete and decrease the internal stress between their components.

This research presents experimental results of mechanical properties and durable performance of mixes that have different percentage of steel slag (BOFS) and determine the optimum percentage of steel slag in Mixture.

\section{EXPERIMENTAL PROGRAM}

A. Materials

1) Cement: Local Portland Cement Type $52.5 \mathrm{~N}$ was used. It is provided by Sinai cement factory. It is conformity with the Egyptian Standard (ES4756-1 /2013). The chemical composition is shown in Table 1 and the physical and mechanical properties are shown in Table 2.

2) Coarse aggregate:

- Crushed Dolomite: Local crushed dolomite of 4.75/12.5 was used. The Physical and mechanical properties are shown in Table 3 and the gradation is shown in Fig. 1.

- BOFS: Basic Oxygen Furnace Slag. It supplied from Helwan steel. The chemical and physical properties are shown in Table 1 and Table 3 respectively. The gradation of BOFS is shown in Fig. 1.

3) Fine aggregate:

- Natural sand of 0/4.75 was used. The specific gravity of sand is 2.67and The Physical properties are shown in Table 3 and the gradation of sand is shown in Fig1.

4) Chemical admixture: The superplasticizer (SP) type (F) is used to achieve good workability. It is density of 1.08 $\mathrm{kg} / \mathrm{lit}$.

5) Water: The clean water is used in mixing and curing.

TABLE 1

\begin{tabular}{l||l||l||l||l||l||l||l||l||l||l||l||}
\multicolumn{9}{c|}{ CHEMICAL COMPOSITION OF PORTLAND CEMENT AND BOFS (MASS \%) } \\
Constituent & SiO2 & Al2O3 & Fe2O3 & CaO & Na2O & K2O & MgO & SO3 & L.O.I & TiO2 & P2O5 \\
\hline PC & 22.12 & 5.56 & 3.69 & 62.87 & 0.26 & 0.11 & 2.36 & 0.91 & 1.22 & -- & -- \\
\hline BOFS & 7 & 2 & 45 & 39.5 & 0.5 & -- & 4 & -- & -- & 0.8 & 1.2
\end{tabular}

TABLE 2

\begin{tabular}{|c|c|c|c|c|c|}
\hline \multirow[b]{3}{*}{ Properties } & \multicolumn{5}{|c|}{ PHYSICAL AND MECHANICAL PROPERTIES OF USED CEMENT CEM I $52.5 \mathrm{~N}$} \\
\hline & Cement & Setting & (Minute) & Compressive stre & $(\mathbf{M P a})$ \\
\hline & $\begin{array}{l}\text { Fineness } \\
\text { (m2/kg) }\end{array}$ & Initial & Final & 2 days & 28 days \\
\hline Test result & 365 & 75 & 205 & Test result & 365 \\
\hline ES 4756-1/2013 limits & $\begin{array}{l}\text { Not less than } \\
275\end{array}$ & $\begin{array}{l}\text { Not less } \\
\text { than } 45\end{array}$ & - & $\begin{array}{l}\text { ES 4756-1/2013 } \\
\text { limits }\end{array}$ & Not less than 275 \\
\hline
\end{tabular}

TABLE 3

PHYSICAL AND MECHANICAL PROPERTIES OF DOLOMITE, SAND AND STEEL SLAG AGGREGATE

\begin{tabular}{|c|c|c|c|c|c|c|}
\hline & \multicolumn{4}{|c|}{ Physical Properties } & \multicolumn{2}{|c|}{ mechanical properties } \\
\hline & $\begin{array}{l}\text { Specific } \\
\text { gravity }\end{array}$ & $\begin{array}{c}\text { Bulk density } \\
(\mathrm{t} / \mathrm{m} 3)\end{array}$ & $\begin{array}{c}\text { Clay and fine } \\
\text { dust content } \\
(\%)\end{array}$ & $\begin{array}{c}\text { Absorption } \\
(\%)\end{array}$ & Coefficient of Impact (\%) & $\begin{array}{c}\text { Aggregate Crushing } \\
\text { value (\%) }\end{array}$ \\
\hline Crushed dolomite & 2.70 & 1.62 & 0.8 & 2.1 & 15 & 23 \\
\hline BOFS & 3.69 & 1.98 & - & 2.7 & 14 & 18 \\
\hline Sand & 2.67 & 1.65 & 0.6 & 1.35 & - & - \\
\hline ES 1109/2008 & - & - & Less than 3.0 & Less than 2.5 & Less than 30 & Less than 30 \\
\hline
\end{tabular}




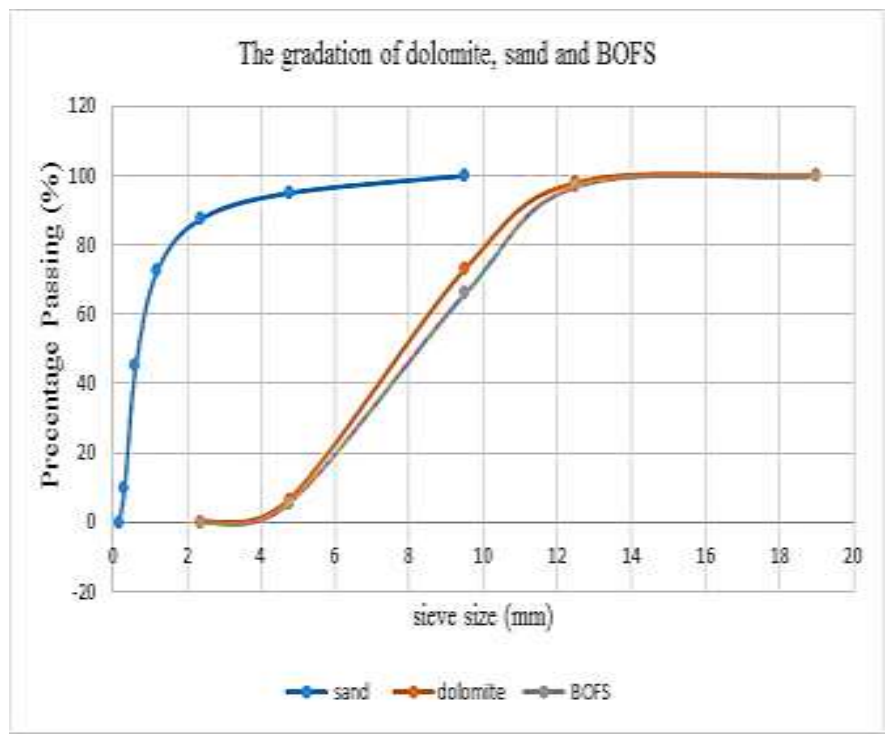

Fig. 1. The gradation of dolomite, sand and BOFS

\section{B. Specimen Preparation and Mixture}

Cubes, cylinders, and beams were prepared to conduct all concrete tests. Cubes of $100 \times 100 \times 100 \mathrm{~mm}$, cylinder of $100 \mathrm{~mm}$ diameters by $200 \mathrm{~mm}$ length and beams of 100x100x500 mm.

Divided as:

1- Compressive strength, indirect tensile strength, and Flexible strength at 7, 28, 56 and 90 days.

2- Bond strength at 28 days on 3 cylinders by $1 \phi 16$ at center.

3- Sulfate attack resistant at 28 days.

The laboratory pan mixer was used in mixing concrete. All samples compacted by using a vibrating table to achieve maximum compaction. The samples were cured in water at $\left(20 \pm 2^{\circ} \mathrm{C}\right)$ after 24 hours of mixing and casting until testing. The sulfate attack resistance was studied by immersing the $100 \mathrm{~mm}$ concrete cube specimens in 5\% sodium sulfate solution with concentration $5 \%$ by weight until the day of testing. The concrete mix proportions are shown in Table 4 .

TABLE 4

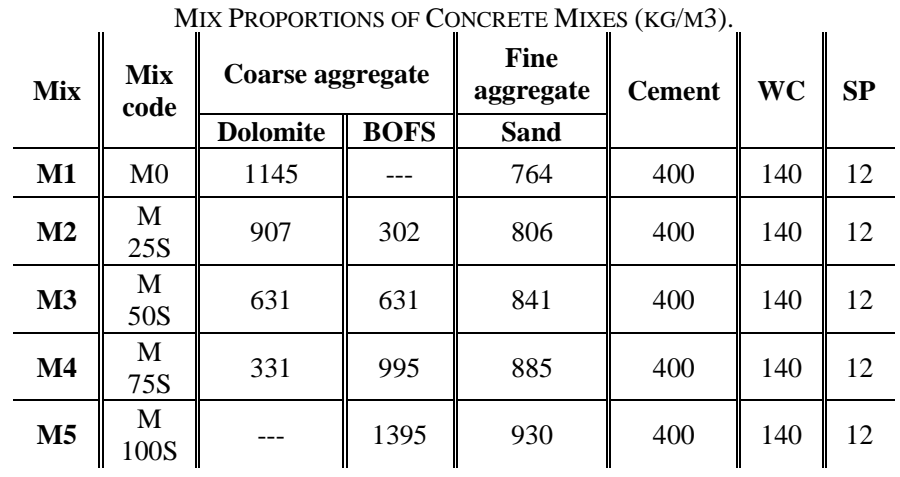

25S, 50S, 75S and 100S: Represent the percentage of coarse aggregate replacement with BOFS

\section{Test Procedure}

The slump test was carried out to determine the workability of concrete mixes. The test performed according to ASTM C143.

The compression strength test was carried out by using test laboratory machine with capacity $2000 \mathrm{kN}$ according to BS EN 12390-2: 2009. The test occurred on $100 \mathrm{~mm}$ concrete cube at the ages of $7,28,56$, and 90 days. The compression strength value was the average of three test result samples for each mixture. The compression strength test carried out on the $100 \mathrm{~mm}$ concrete specimen which immersed in sodium sulfate solution with concentration $5 \%$ to study the impact of sulfate attack on concrete specimens. The test was performed at the age of 28days.

The Splitting tensile strength test was performed at7, 28, 56 and 90 days according to BS EN 12390-6:2009 standard. Three cylinders for each mixture $100 * 200 \mathrm{~mm}$ prepared to test at different test deadline by using same compression machine.

The Flexural strength test was performed at 7, 28, 56, and 90 days according to ASTM C78. 12 beams were prepared $100 * 100 * 500 \mathrm{~mm}$ to test at each deadline. The beam was simply supported as $450 \mathrm{~mm}$ clear span, the testing machine with $100 \mathrm{kN}$ capacity and $0.1 \mathrm{kN}$ accuracy was used for testing.

Bond strength between reinforcing bar and the surrounding concrete was determined by pulling out the steel bar from the concrete specimen using universal testing machine with 30-ton capacity and 0.1-ton accuracy. The tests were carried out according BS 1881: part 207: 1992.

\section{TESTRESULTSANDANALYSIS}

The ensuing subsections present analysis and discussion of the results of each conducted test on the investigated mixtures.

\section{A. Fresh properties}

\section{A.1. slump test}

Table 5 and Fig. 2 show the effect of BOFS on workability. The results show that the use of steel slag aggregate reduces the workability of concrete. because of the angular shape of the BOFS that increase the bond with cement paste and stability against collapsing. These results are in line with the finding of Kothai et al [5].

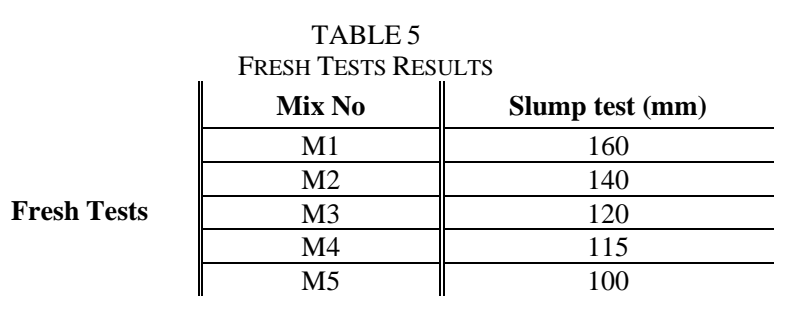

$=$

\section{B. Hardened properties}

\section{B.1. Compressive strength}

Table 6 and Fig. 3 show the effect of BOFS on the compression test. The results show that using steel slag as coarse aggregate increase the compressive strength of all 
mixes because of the rough surface texture and the angular shape of the BOFS that led to the high bond matrix between slag and cement paste. The use of $25 \%$ steel slag aggregate led to $12 \%$ increase in compressive strength, $50 \%$ steel slag aggregate led to $10.5 \%$ increase in compressive strength, $75 \%$ steel slag aggregate led to $5.6 \%$ increase in compressive strength, and $100 \%$ replacement led to very similar value to the control mix.

\section{B.2. Splitting tensile strength}

Table 6 and Fig. 4 show the effect of BOFS on splitting tensile test. The results show that using steel slag as coarse aggregate increase the splitting tensile strength of all mixes. The mix M3 (50\% BOFS replacement) are better tensile strength comparing to control mix. whereat use 50\% BOFS replacement get increase $17 \%$ on indirect tensile strength from control mix at 90 days, and at an early age at 7 days get increase $39.4 \%$ from control mix.

\section{B.3. Flexural strength}

Table 6 and Fig. 5 show the effect of BOFS on flexural test. The results show that using steel slag as coarse aggregate increase the flexural strength of all mixes. The mix M2 (25\% BOFS replacement) are better flexural strength comparing to control mix. When we use 25\% BOFS replacement gets increase $20 \%$ on flexural strength from control mix at 90 days, and at an early age at 7 days get increase $30.8 \%$ from control mix. Because of physical properties of BOFS such as the rough surface texture and the angular shape of the BOFS.

\section{B.4. Bond strength}

Table 6 and Fig. 6 show the effect of BOFS on the bond test. The results show that All mixes have BOFS (M2, M3, M4, and M5) are better bond strength than control mix (M1) because of physical properties of BOFS such as the rough surface texture, angular shape, high porosity, and the high bond matrix between slag and cement paste as a result from interlock the cement paste into open holes on the external surface of aggregate. The mix M2 (25\% BOFS replacement) are better bond strength comparing to the control mix. When we use $25 \%$ BOFS replacement get increase $28.5 \%$ on bond strength from control mix at 28 days.

\section{Durability properties}

\section{C.1 Sulfate Resistance}

Table 7 and Fig. 7 show the effect of BOFS on sulfate resistance test. The results show that all mixtures were decreased in compression strength after sulfate attacking. M5 (100\% replacement) is similar decreasing to the control mix.

TABLE 6

\begin{tabular}{|c|c|c|c|c|c|c|}
\hline \multicolumn{7}{|c|}{ HARDENED TESTS RESULTS } \\
\hline \multirow{7}{*}{$\begin{array}{l}\text { Hardened } \\
\text { tests }\end{array}$} & Tests & $\begin{array}{c}\text { Mix } \\
\text { No }\end{array}$ & $\begin{array}{c}\text { At } \\
\text { 7days }\end{array}$ & $\begin{array}{c}\text { At } \\
\text { 28days }\end{array}$ & $\begin{array}{c}\text { At } \\
\text { 56days }\end{array}$ & $\begin{array}{c}\text { At } \\
\text { 90days }\end{array}$ \\
\hline & \multirow{5}{*}{ Unit weight } & M1 & -- & 2.38 & -- & -- \\
\hline & & M2 & -- & 2.5 & -- & -- \\
\hline & & M3 & -- & 2.68 & -- & -- \\
\hline & & M4 & -- & 2.74 & -- & -- \\
\hline & & M5 & -- & 2.81 & -- & -- \\
\hline & Compression & M1 & 35.7 & 51 & 57.5 & 62.5 \\
\hline
\end{tabular}

\begin{tabular}{||c||c||c||c||c||c}
\multirow{4}{*}{ strength } & M2 & 53 & 58 & 64 & 70 \\
\cline { 2 - 5 } & M3 & 52 & 57 & 63 & 69 \\
\cline { 2 - 5 } & M4 & 50.5 & 56 & 62 & 66 \\
\cline { 2 - 5 } & M5 & 48 & 51 & 60 & 64 \\
\hline \multirow{4}{*}{$\begin{array}{c}\text { Slitting } \\
\text { tensile } \\
\text { strength }\end{array}$} & M1 & 2.87 & 3.72 & 4.5 & 4.7 \\
\cline { 2 - 5 } & M2 & 3.18 & 4.14 & 4.78 & 5.14 \\
\cline { 2 - 5 } & M3 & 4 & 4.78 & 4.9 & 5.5 \\
\cline { 2 - 5 } & M4 & 3.97 & 4.32 & 4.75 & 5.31 \\
\cline { 2 - 5 } & M5 & 3.66 & 4.27 & 4.71 & 5.16 \\
\hline \multirow{4}{*}{$\begin{array}{c}\text { Flexural } \\
\text { strength }\end{array}$} & M1 & 3.87 & 3.89 & 4 & 4.5 \\
\cline { 2 - 5 } & M2 & 4.68 & 5.09 & 5.13 & 5.4 \\
\cline { 2 - 5 } & M3 & 4.1 & 4.2 & 4.73 & 4.91 \\
\cline { 2 - 5 } & M4 & 4.09 & 4.13 & 4.43 & 4.93 \\
\cline { 2 - 5 } & M5 & 3.89 & 4.15 & 4.35 & 4.56 \\
\hline \multirow{5}{*}{$\begin{array}{c}\text { Bond } \\
\text { strength }\end{array}$} & M1 & -- & 6.5 & -- & -- \\
\cline { 2 - 5 } & M2 & -- & 8.35 & -- & -- \\
\cline { 2 - 5 } & M3 & -- & 7.9 & -- & -- \\
\cline { 2 - 5 } & M4 & -- & 7.75 & -- & -- \\
\cline { 2 - 5 } & M5 & -- & 7.8 & -- & --
\end{tabular}

TABLE 7

\begin{tabular}{|c|c|c|c|}
\hline \multicolumn{4}{|c|}{ DURABILITY TESTS RESULTS } \\
\hline \multirow{6}{*}{$\begin{array}{l}\text { Durability } \\
\text { Tests }\end{array}$} & Mix No & $\begin{array}{c}\text { Compression } \\
\text { strength at } 28 \text { day }\end{array}$ & $\begin{array}{c}\text { Sulfate resistance } \\
\text { at } 28 \text { days }\end{array}$ \\
\hline & M1 & 51 & 50 \\
\hline & M2 & 58 & 54 \\
\hline & M3 & 57 & 55 \\
\hline & M4 & 56 & 53 \\
\hline & M5 & 51 & 50 \\
\hline
\end{tabular}

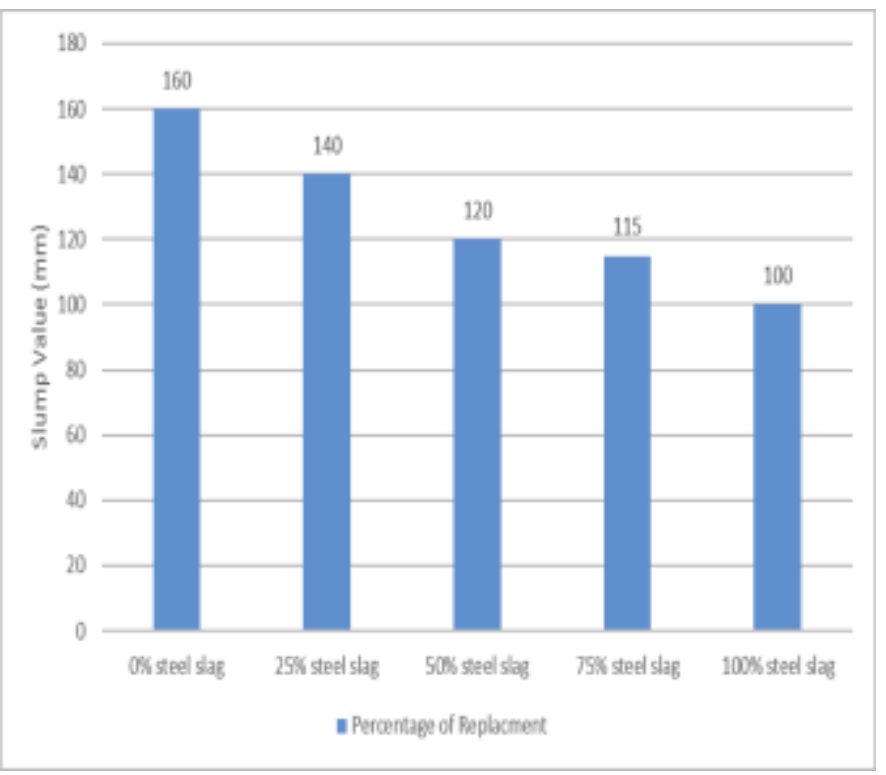

Fig. 2 Slump Value of Different Mixes 


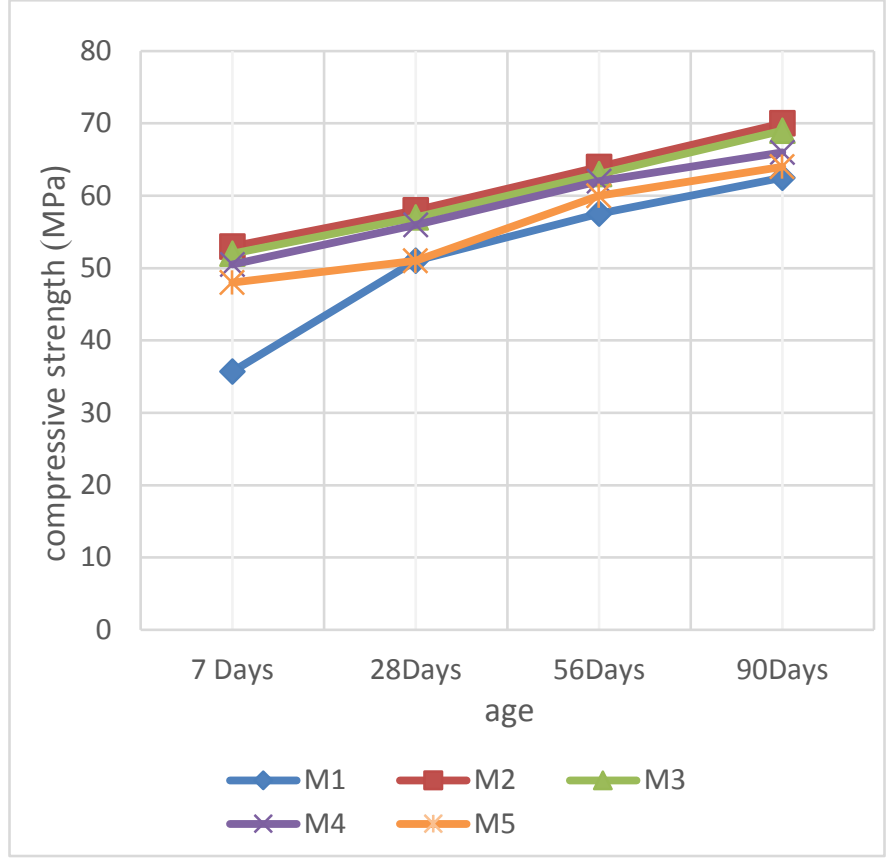

Fig. 3. The Effect of use BOFS on Compressive Strength

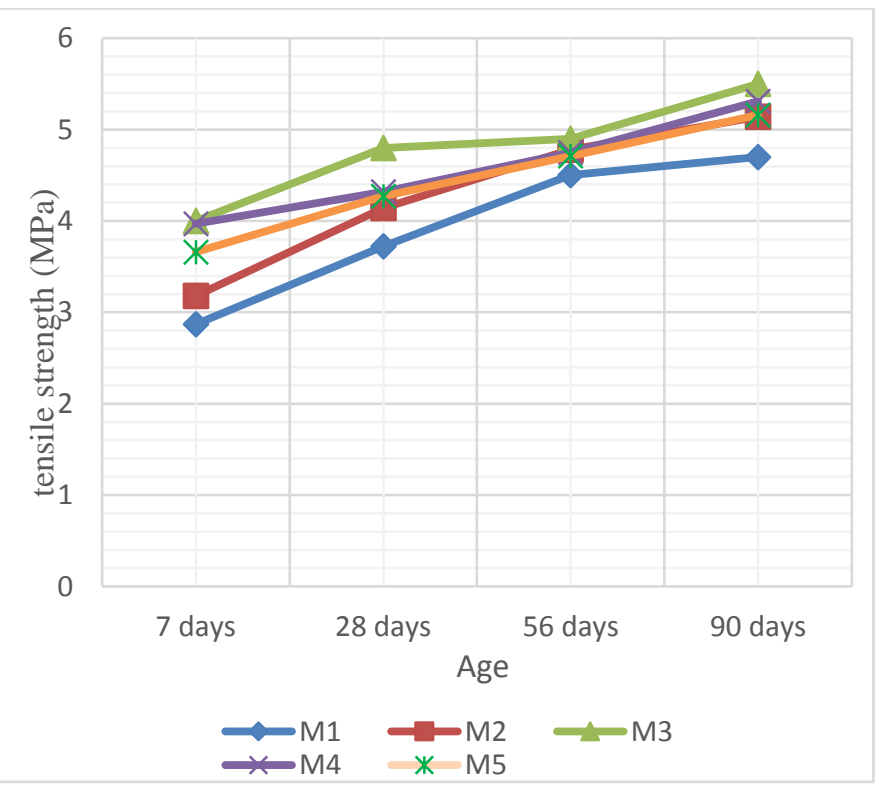

Fig. 4. The Effect of use BOFS on Tension Strength

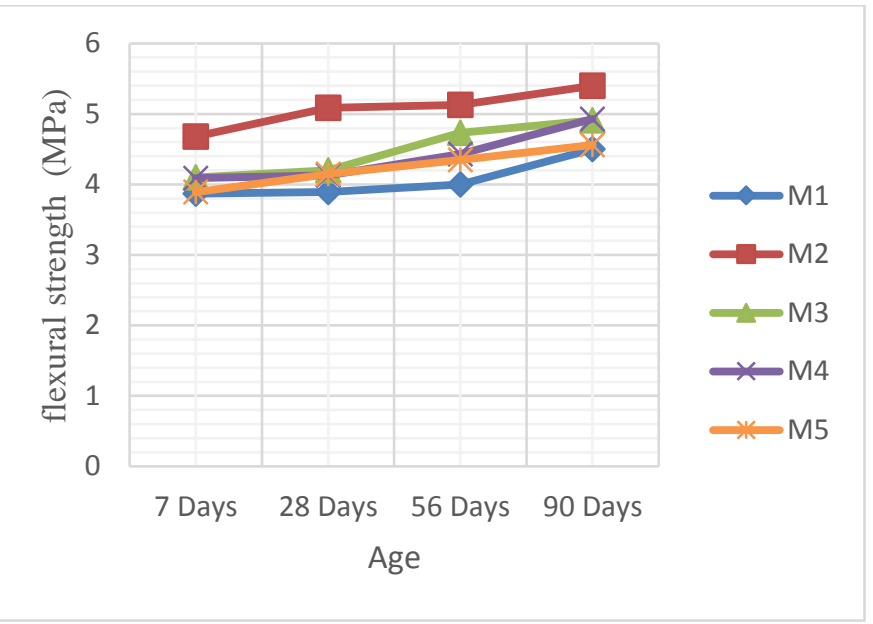

Fig. 5. The Effect of use BOFS on Flexural Strength.

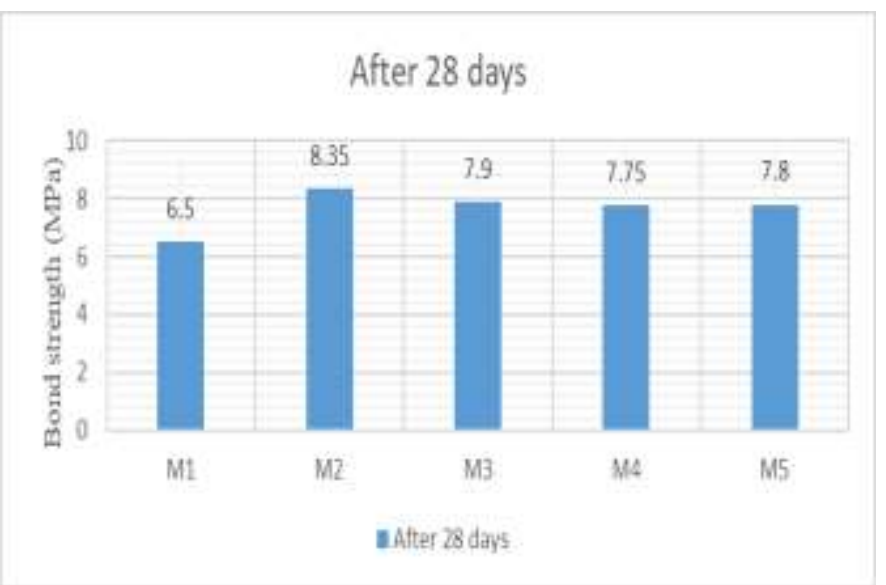

Fig. 6 The Effect of use BOFS on Bond Strength

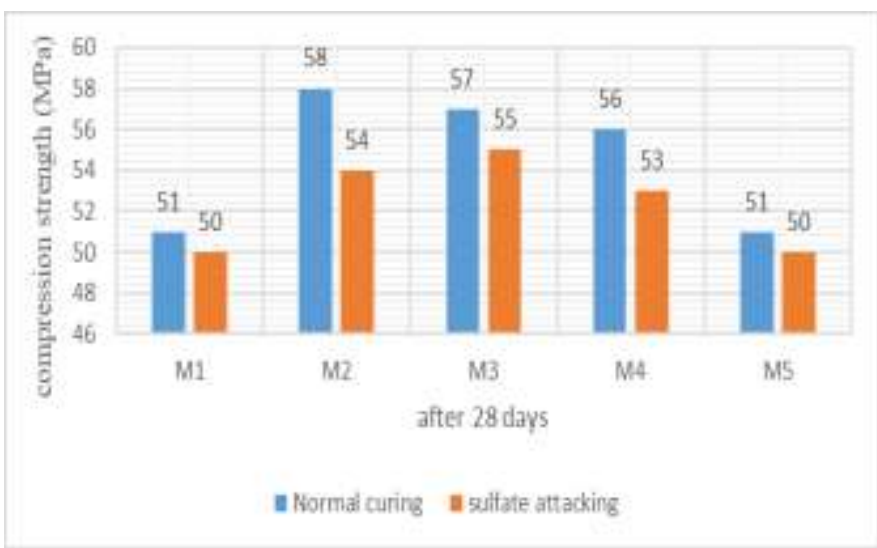

Fig. 7. The Effect of use BOFS on Sulfate Attacking resistance

\section{CONCLUSION}

- The use of BOFS reduces the fresh properties where that shown as the slump reduced from $160 \mathrm{~mm}$ at zero steel aggregate to $100 \mathrm{~mm}$ at $100 \%$ steel slag.

- The BOFS increase the compressive strength of concrete, and the results show that $25 \%, 50 \%$, and $75 \%$ BOFS increase the strength by $12 \%, 10.5 \%$, and $5.6 \%$ respectively, and $100 \%$ replacement very similar to control mix. 
- The BOFS increase the flexural strength of concrete, where $25 \%, 50 \%$, and $75 \%$ BOFS increase the strength by $20 \%, 8.8 \%$, and $8.8 \%$ respectively, and $100 \%$ replacement very similar to control mix.

- The BOFS increase the tensile strength of concrete. Replacement with 50\% BOFS increase the strength by $17 \%$ increase, and $100 \%$ BOFS led to $10 \%$ increase in strength.

- The BOFS increase the bond strength of concrete, where $25 \%$ BOFS increase the strength by $28.5 \%$ increase, and $100 \%$ replacement led to $20 \%$ increase.

- BOFS has positive effect on concrete properties for all mixes due to its physical properties, and safe to use in ecofriendly rigid pavement

\section{REFERENCES}

[1] K. P. Verian, N. M. Whiting, J. Olek, and M. B. Snyder,"Using recycled concrete as aggregate in concrete pavements to reduce materials cost", Joint Transportation research progrm publication. doi:https://doi.org/10.573/1288284315220, 2013.

[2] C. Kambole, P. Paige-green, and W. Kupolati, "Basic Oxgen Furnace Slag for Road Pavements: a review of Material Characteristics and Performance for effective utilisation in Southern Africa ", Construction and Building Materials, 2017.

[3] N. Grubeša, I. Barisic, A. Fucic, and S. S. Bansode, "Characteristics and Uses of Steel Slag in Building Construction ". Woodhead Publishing, 2016.

[4] H. Qasrawi, F. Shalabi, and I. Asi, "Use of low $\mathrm{CaO}$ unprocessed steel slag in concrete as fine aggregate", Construction and Building Materials, 23(2), 1118-1125, 2009.

[5] P. S. Kothai, R. Malathy, "Enhancement of concrete properties by steel slag as partial replacement material for coarse aggregate", Australian Journal of Basic and Applied Sciences, 278-285, 2013.

[6] R. lizadeh, M. Chini, P. Ghods, M. Hoseini, S. Montazer, and M. Shekarchi, "Utilization of electric arc furnace slag as aggregates in concrete". Bucharest, Romania: Proceedings of the 6th CANMET/ACI international conference on recent advances in concrete technology, 2003.

[7] M. Ameri, H. Shahabishahmiri, and S. Kazemzadehazad, "Evaluation of the use of steel slag in concrete", ARRB Conference. Western Australia, Australia, 2012. 